4

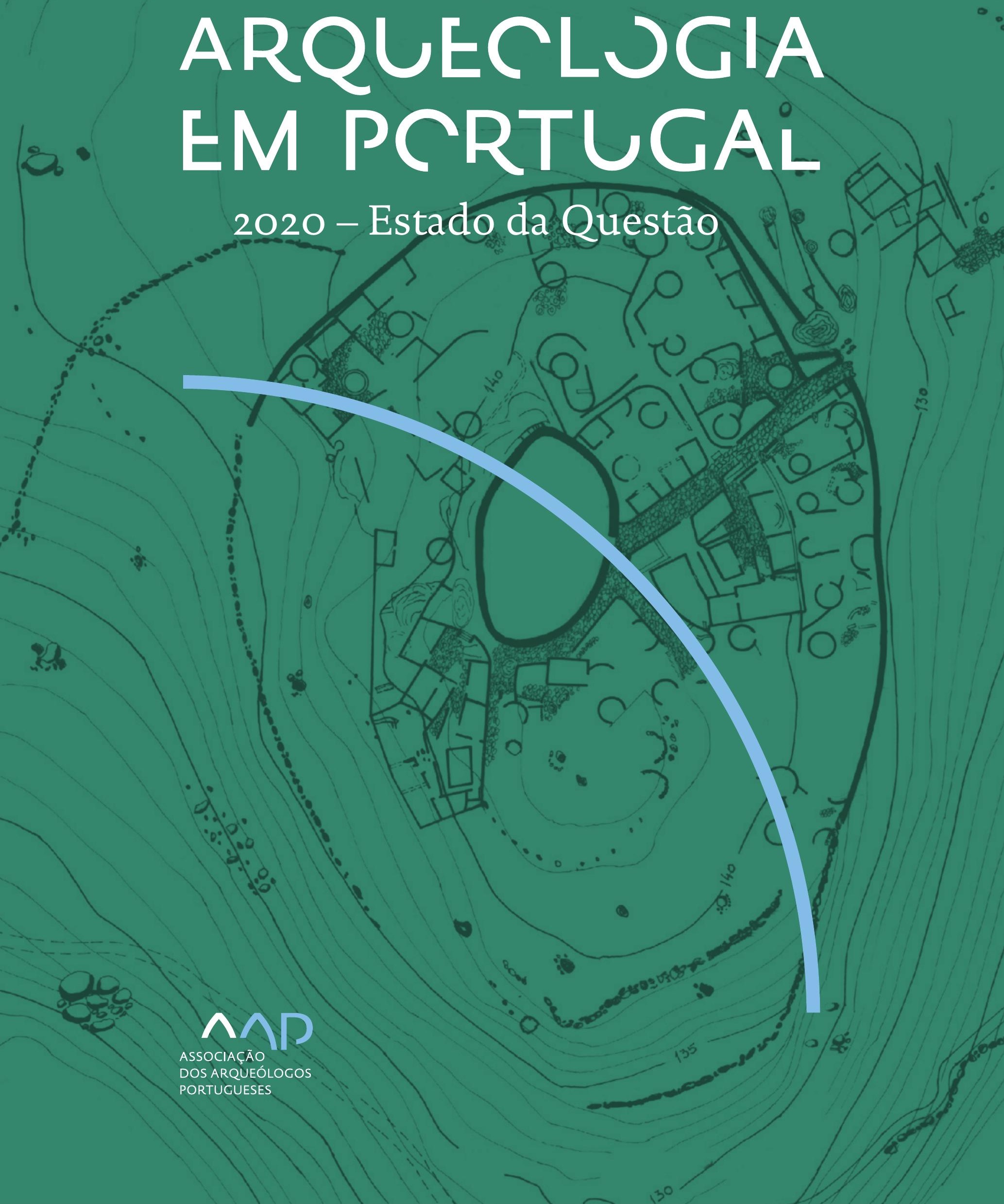


Coordenação editorial: José Morais Arnaud, César Neves e Andrea Martins Design gráfico: Flatland Design

AAP - ISBN: 978-972-9451-89-8

CITCEM - ISBN: 978-989-8970-25-1

Associação dos Arqueólogos Portugueses e CITCEM

Lisboa, 2020

O conteúdo dos artigos é da inteira responsabilidade dos autores. Sendo assim a Associação dos Arqueólogos Portugueses declina qualquer responsabilidade por eventuais equívocos ou questões de ordem ética e legal.

Desenho de capa:

Planta do castro de Monte Mozinho (Museu Municipal de Penafiel).

\section{$\hat{\wedge} \mathrm{P}$}

DOS ARQUEÓLOGOS PORTUGUESES

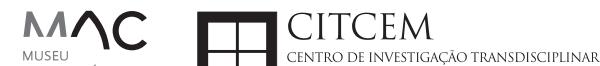
MUSEU
ARQUELLÓGICO
DO CARMO
U.PORTO

FLUP FACULDADE DE LETRAS
UNIVERSIDADE DO PORTO

Apoio

EC para a Ciência 


\section{Índice}

15 Prefácio

José Morais Arnaud

\section{Historiografia e Teoria}

17 Território, comunidade, memória e emoção: a contribuição da história da arqueologia (algumas primeiras e breves reflexões)

Ana Cristina Martins

25 Como descolonizar a arqueologia portuguesa?

Rui Gomes Coelho

41 Arqueologia e Modernidade: uma revisitação pessoal e breve de alguns aspetos da obra homónima de Julian Thomas de 2004

Vítor Oliveira Jorge

57 Dados para a História das Mulheres na Arqueologia portuguesa, dos finais do século XIX aos inícios do século XX: números, nomes e tabelas

Filipa Dimas / Mariana Diniz

73 Retractos da arqueologia portuguesa na imprensa: (in)visibilidades no feminino

Catarina Costeira / Elsa Luís

85 Arqueologia e Arqueólogos no Norte de Portugal Jacinta Bugalhão

101 Vieira Guimarães (1864-1939) e a arqueologia em Tomar: uma abordagem sobre o território e as gentes

João Amendoeira Peixoto / Ana Cristina Martins

115 Os memoráveis? A arqueologia algarvia na imprensa nacional e regional na presente centúria (2001-2019): características, visões do(s) passado(s) e a arqueologia

enquanto marca

Frederico Agosto / João Silva

129 A Evolução da Arqueologia Urbana e a Valorização Patrimonial no Barlavento Algarvio: Os casos de Portimão e Silves

Artur Mateus / Diogo Varandas / Rafael Boavida

\section{Gestão, Valorização e Salvaguarda do Património}

145 O Caderno Reivindicativo e as condições de trabalho em Arqueologia Miguel Rocha / Liliana Matias Carvalho / Regis Barbosa / Mauro Correia / Sara Simões / Jacinta Bugalhão / Sara Brito / Liliana Veríssimo Carvalho / Richard Peace / Pedro Peça / Cézer Santos

155 Os Estudos de Impacte Patrimonial como elemento para uma estratégia sustentável de minimização de impactes no âmbito de reconversões agrícolas Tiago do Pereiro

165 Salvaguarda de Património arqueológico em operações florestais: gestão e sensibilização Filipa Bragança / Gertrudes Zambujo / Sandra Lourenço / Belém Paiva / Carlos Banha / Frederico Tatá Regala / Helena Moura / Jacinta Bugalhão / João Marques / José Correia / Pedro Faria / Samuel Melro

179 Os valores do Património: uma investigação sobre os Sítios Pré-históricos de Arte Rupestre do Vale do Rio Côa e de Siega Verde José Paulo Francisco 
189 Conjugando recursos arqueológicos e naturais para potenciar as visitas ao Geoparque Litoral de Viana do Castelo (Noroeste de Portugal)

Hugo A. Sampaio / Ana M.S. Bettencourt / Susana Marinho / Ricardo Carvalhido

203 Áreas de Potencial Arqueológico na Região do Médio Tejo: Modelo Espacial Preditivo Rita Ferreira Anastácio / Ana Filipa Martins / Luiz Oosterbeek

223 Património Arqueológico e Gestão Territorial: O contributo da Arqueologia para a revisão do PDM de Avis

Ana Cristina Ribeiro

237 A coleção arqueológica do extinto Museu Municipal do Porto - Origens, Percursos e Estudos

Sónia Couto

251 Valpaços - uma nova carta arqueológica

Pedro Pereira / Maria de Fátima Casares Machado

263 Arqueologia na Cidade de Peniche

Adriano Constantino / Luís Rendeiro

273 Arqueologia Urbana: a cidade de Lagos como caso de Estudo Cátia Neto

285 Estratégias de promoção do património cultural subaquático nos Açores. O caso da ilha do Faial

José Luís Neto / José Bettencourt / Luís Borges / Pedro Parreira

297 Carta Arqueológica da Cidade Velha: Uma primeira abordagem

Jaylson Monteiro / Nireide Tavares / Sara da Veiga / Claudino Ramos / Edson Brito /

Carlos Carvalho / Francisco Moreira / Adalberto Tavares

311 Antropologia Virtual: novas metodologias para a análise morfológica e funcional Ricardo Miguel Godinho / Célia Gonçalves

\section{Didáctica da Arqueologia}

327 Como os projetos de Arqueologia podem contribuir para uma comunidade culturalmente mais consciente Alexandra Figueiredo / Claúdio Monteiro / Adolfo Silveira / Ricardo Lopes

337 Educação Patrimonial - Um cidadão esclarecido é um cidadão ativo! Ana Paula Almeida

351 A aproximação da Arqueologia à sala de aula: um caso de estudo no $3^{\circ}$ ciclo do Ensino Básico Luís Serrão Gil

363 Arqueologia 3.o - Pensar e comunicar a Arqueologia para um futuro sustentável Mónica Rolo

377 “Conversa de Arqueólogos" - Divulgar a Arqueologia em tempos de Pandemia Diogo Teixeira Dias

389 Escola Profissional de Arqueologia: desafios e oportunidades Susana Nunes / Dulcineia Pinto / Júlia Silva / Ana Mascarenhas

399 Os Museus de Arqueologia e os Jovens: a oferta educativa para o público adolescente Beatriz Correia Barata / Leonor Medeiros

411 O museu universitário como mediador entre a ciência e a sociedade: o exemplo da secção de arqueologia no Museu de História Natural e da Ciência da Universidade do Porto (MHNC-UP)

Rita Gaspar 
421 Museu de Lanifícios: Real Fábrica de Panos. Atividades no âmbito da Arqueologia Beatriz Correia Barata / Rita Salvado

427 Arqueologia Pública e o caso da localidade da Mata (Torres Novas) Cláudia Manso / Ana Rita Ferreira / Cristiana Ferreira / Vanessa Cardoso Antunes

431 Do sítio arqueológico ao museu: um percurso (também) didático Lídia Fernandes

447 Estão todos convidados para a Festa! E para dançar também... O projecto do Serviço Educativo do Museu Arqueológico do Carmo na $5^{\underline{a}}$ Edição da Festa da Arqueologia Rita Pires dos Santos

459 O “Clã de Carenque”, um projeto didático de arqueologia Eduardo Gonzalez Rocha

469 Mediação cultural: peixe que puxa carroça nas Ruínas Romanas de Troia Inês Vaz Pinto / Ana Patrícia Magalhães / Patrícia Brum / Filipa Santos

481 Didática Arqueológica, experiências do Projeto Mértola Vila Museu Maria de Fátima Palma / Clara Rodrigues / Susana Gómez / Lígia Rafael

\section{Arte Rupestre}

497 Os inventários de arte rupestre em Portugal Mila Simões de Abreu

513 O projeto FIRST-ART - conservação, documentação e gestão das primeiras manifestações de arte rupestre no Sudoeste da Península Ibérica: as grutas do Escoural e Maltravieso Sara Garcês / Hipólito Collado / José Julio García Arranz / Luiz Oosterbeek / António Carlos Silva / Pierluigi Rosina / Hugo Gomes / Anabela Borralheiro Pereira / George Nash / Esmeralda Gomes / Nelson Almeida / Carlos Carpetudo

523 Trabalhos de documentação de arte paleolítica realizados no âmbito do projeto PalæoCôa André Tomás Santos / António Fernando Barbosa / Luís Luís / Marcelo Silvestre / Thierry Aubry

537 Imagens fantasmagóricas, silhuetas elusivas: as figuras humanas na arte do Paleolítico Superior da região do Côa Mário Reis

$55^{1}$ Os motivos zoomórficos representados nas placas de tear de Vila Nova de São Pedro (Azambuja, Portugal) Andrea Martins / César Neves / José M. Arnaud / Mariana Diniz

571 Arte Rupestre do Monte de Góios (Lanhelas, Caminha). Síntese dos resultados dos trabalhos efectuados em 2007-2009 Mário Varela Gomes

599 Gravuras rupestres de barquiformes no Monte de S. Romão, Guimarães, Noroeste de Portugal Daniela Cardoso

613 Círculos segmentados gravados na Bacia do Rio Lima (Noroeste de Portugal): contributos para o seu estudo Diogo Marinho / Ana M.S. Bettencourt / Hugo Aluai Sampaio

631 Equídeos gravados no curso inferior do Rio Mouro, Monção (NW Portugal). Análise preliminar Coutinho, L.M. / Bettencourt, A.M.S / Sampaio, Hugo A.S

645 Paletas na Arte Rupestre do Noroeste de Portugal. Inventário preliminar Bruna Sousa Afonso / Ana M. S. Bettencourt / Hugo A. Sampaio 


\section{Pré-História}

661 O projeto Miño/Minho: balanço de quatro anos de trabalhos arqueológicos Sérgio Monteiro-Rodrigues / João Pedro Cunha-Ribeiro / Eduardo Méndez-Quintas / Carlos Ferreira / Pedro Xavier / José Meireles / Alberto Gomes / Manuel Santonja / Alfredo Pérez-González

677 A ocupação paleolítica da margem esquerda do Baixo Minho: a indústria lítica do sítio de Pedreiras 2 (Monção, Portugal) e a sua integração no contexto regional Carlos Ferreira / João Pedro Cunha-Ribeiro / Sérgio Monteiro-Rodrigues / Eduardo Méndez-Quintas / Pedro Xavier / José Meireles / Alberto Gomes / Manuel Santonja / Alfredo Pérez-González

693 O sítio acheulense do Plistocénico médio da Gruta da Aroeira Joan Daura / Montserrat Sanz / Filipa Rodrigues / Pedro Souto / João Zilhão

703 As sociedades neandertais no Barlavento algarvio: modelos preditivos com recurso aos SIG

Daniela Maio

715 A utilização de quartzo durante o Paleolítico Superior no território dos vales dos rios Vouga e Côa

Cristina Gameiro / Thierry Aubry / Bárbara Costa / Sérgio Gomes / Luís Luís / Carmen Manzano / André Tomás Santos

733 Uma perspetiva diacrónica da ocupação do concheiro do Cabeço da Amoreira (Muge, Portugal) a partir da tecnologia lítica Joana Belmiro / João Cascalheira / Célia Gonçalves

745 Novos dados sobre a Pré-história Antiga no concelho de Palmela. A intervenção arqueológica no sítio do Poceirão I

Michelle Teixeira Santos

757 Problemas em torno de Datas Absolutas Pré-Históricas no Norte do Alentejo Jorge de Oliveira

771 Povoamento pré-histórico nas áreas montanhosas do NO de Portugal: o Abrigo 1 de Vale de Cerdeira Pedro Xavier / José Meireles / Carlos Alves

783 Apreciação do povoamento do Neolítico Inicial na Baixa Bacia do Douro. A Lavra I (Serra da Aboboreira) como caso de estudo Maria de Jesus Sanches

797 O Processo de Neolitização na Plataforma do Mondego: os dados do Sector C do Outeiro dos Castelos de Beijós (Carregal do Sal)

João Carlos de Senna-Martinez / José Manuel Quintã Ventura / Andreia Carvalho / Cíntia Maurício

823 Novos trabalhos na Lapa da Bugalheira (Almonda, Torres Novas) Filipa Rodrigues / Pedro Souto / Artur Ferreira / Alexandre Varanda / Luís Gomes / Helena Gomes / João Zilhão

837 A pedra polida e afeiçoada do sítio do Neolítico médio da Moita do Ourives (Benavente, Portugal)

César Neves

857 Casal do Outeiro (Encarnação, Mafra): novos contributos para o conhecimento do povoamento do Neolítico final na Península de Lisboa.

Cátia Delicado / Carlos Maneira e Costa / Marta Miranda / Ana Catarina Sousa

873 Stresse infantil, morbilidade e mortalidade no sítio arqueológico do Neolítico Final/ Calcolítico ( $4^{\circ}$ e $3^{\circ}$ milénio a.C.) do Monte do Carrascal 2 (Ferreira do Alentejo, Beja) Liliana Matias de Carvalho / Sofia N. Wasterlain 
885 Come together: O Conjunto Megalítico das Motas (Monção, Viana do Castelo) e as expressões Campaniformes do Alto Minho Ana Catarina Basílio / Rui Ramos

899 Trabalhos arqueológicos no sítio Calcolítico da Pedreira do Poio Carla Magalhães / João Muralha / Mário Reis / António Batarda Fernandes

913 O sítio arqueológico de Castanheiro do Vento. Da arquitectura do sítio à arquitectura de um território João Muralha Cardoso

925 Estudo zooarqueológico das faunas do Calcolítico final de Vila Nova de São Pedro (Azambuja, Portugal): Campanhas de 2017 e 2018 Cleia Detry / Ana Catarina Francisco / Mariana Diniz / Andrea Martins / César Neves / José Morais Arnaud

943 As faunas depositadas no Museu Arqueológico do Carmo provenientes de Vila Nova de São Pedro (Azambuja): as campanhas de 1937 a 1967 Ana Catarina Francisco / Cleia Detry / César Neves / Andrea Martins / Mariana Diniz / José Morais Arnaud

959 Análise funcional de material lítico em sílex do castro de Vila Nova de S. Pedro (Azambuja, Portugal): uma primeira abordagem Rafael Lima

971 O recinto da Folha do Ouro 1 (Serpa) no contexto dos recintos de fossos calcolíticos alentejanos

António Carlos Valera / Tiago do Pereiro / Pedro Valério / António M. Monge Soares

\section{Proto-História}

987 Produção de sal marinho na Idade do Bronze do noroeste Português. Alguns dados para uma reflexão

Ana M. S. Bettencourt / Sara Luz / Nuno Oliveira / Pedro P. Simões / Maria Isabel C. Alves / Emílio Abad-Vidal

1001 A estátua-menir do Pedrão ou de São Bartolomeu do Mar (Esposende, noroeste de Portugal) no contexto arqueológico da fachada costeira de entre os rios Neiva e Cávado Ana M. S. Bettencourt / Manuel Santos-Estévez / Pedro Pimenta Simões / Luís Gonçalves

1015 O Castro do Muro (Vandoma/Baltar, Paredes) - notas para uma biografia de ocupação da Idade do Bronze à Idade Média

Maria Antónia D. Silva / Ana M. S. Bettencourt / António Manuel S. P. Silva / Natália Félix

1031 Do Bronze Final à Idade Média - continuidades e hiatos na ocupação de Povoados em Oliveira de Azeméis João Tiago Tavares / Adriaan de Man

1041 As faunas do final da Idade do Bronze no Sul de Portugal: leituras desde o Outeiro do Circo (Beja)

Nelson J. Almeida / Íris Dias / Cleia Detry / Eduardo Porfírio / Miguel Serra

1055 A Espada do Monte das Oliveiras (Serpa) - uma arma do Bronze Pleno do Sudoeste Rui M. G. Monge Soares / Pedro Valério / Mariana Nabais / António M. Monge Soares

1065 São Julião da Branca (Albergaria-a-Velha) - Investigação e valorização de um povoado do Bronze Final

António Manuel S. P. Silva / Paulo A. P. Lemos / Sara Almeida e Silva / Edite Martins de Sá

1083 Do castro de S. João ao Mosteiro de Santa Clara: notícia de uma intervenção arqueológica, em Vila do Conde Rui Pinheiro 
1095 O castro de Ovil (Espinho), um quarto de século de investigação - resultados e questões em aberto

Jorge Fernando Salvador / António Manuel S. P. Silva

1111 O Castro de Salreu (Estarreja), um povoado proto-histórico no litoral do Entre Douro e Vouga

Sara Almeida e Silva / António Manuel S. P. Silva / Paulo A. P. Lemos / Edite Martins de Sá

1127 Castro de Nossa Senhora das Necessidades (Sernancelhe): uma primeira análise artefactual Telma Susana O. Ribeiro

${ }_{1141}$ A cividade de Bagunte. O estado atual da investigação Pedro Brochado de Almeida

1153 Zoomorfos na cerâmica da Idade do Ferro no NW Peninsular: inventário, cronologias e significado Nuno Oliveira / Cristina Seoane

1163 Vasos gregos em Portugal: diferentes maneiras de contar a história do intercâmbio cultural na Idade do Ferro

Daniela Ferreira

1175 Os exotica da necrópole da Idade do Ferro do Olival do Senhor dos Mártires (Alcácer do Sal) no seu contexto regional

Francisco B. Gomes

\section{Antiguidade Clássica e Tardia}

1191 O uso de madeira como combustível no sítio da Quinta de Crestelos (Baixo Sabor): da Idade do Ferro à Romanização Filipe Vaz / João Tereso / Sérgio Simões Pereira / José Sastre / Javier Larrazabal Galarza / Susana Cosme / José António Pereira / Israel Espi

1207 Cultivos de Época Romana no Baixo Sabor: continuidade em tempos de mudança? João Pedro Tereso / Sérgio Simões Pereira / Filipe Santos / Luís Seabra / Filipe Vaz

1221 A casa romana na Hispânia: aplicação dos modelos itálicos nas províncias ibéricas Fernanda Magalhães / Diego Machado / Manuela Martins

1235 As pinturas murais romanas da Rua General Sousa Machado, n. ${ }^{5}$ 1, Chaves José Carvalho

1243 Trás do Castelo (Vale de Mir, Pegarinhos, Alijó) - Uma exploração agrícola romana do Douro

Tony Silvino / Pedro Pereira

1255 A sequência de ocupação no quadrante sudeste de Bracara Augusta: as transformações de uma unidade doméstica Lara Fernandes / Manuela Martins

1263 Os Mosaicos com decoração geométrica e geométrico-vegetalista dos sítios arqueológicos da área do Conuentus Bracaraugustanus. Novas abordagens quanto à conservação, restauro, decoração e datação Maria de Fátima Abraços / Licínia Wrench

1277 “Casa Romana” do Castro de São Domingos (Cristelos, Lousada): Escavação, Estudo e Musealização Paulo André de P. Lemos

1291 A arqueobotânica no Castro de Guifões (Matosinhos, Noroeste de Portugal): O primeiro estudo carpológico

Luís Seabra / Andreia Arezes / Catarina Magalhães / José Varela / João Pedro Tereso 
1305 Um Horreum Augustano na Foz do Douro (Monte do Castelo de Gaia, Vila Nova de Gaia) Rui Ramos

1311 Ponderais romanos na Lusitânia: padrões, formas, materiais e contextos de utilização Diego Barrios Rodríguez

1323 Um almofariz centro-itálico na foz do Mondego

Marco Penajoia

1335 Estruturas romanas de Carnide - Lisboa Luísa Batalha / Mário Monteiro / Guilherme Cardoso

1347 O contexto funerário do sector da "necrópole NO" da Rua das Portas de S. Antão (Lisboa): o espaço, os artefactos, os indivíduos e a sua interconectividade na interpretação do passado Sílvia Loja, José Carlos Quaresma, Nelson Cabaço, Marina Lourenço, Sílvia Casimiro, Rodrigo Banha da Silva, Francisca Alves-Cardoso

${ }_{1361}$ Povoamento em época Romana na Amadora - resultados de um projeto pluridisciplinar Gisela Encarnação / Vanessa Dias

1371 A Arquitectura Residencial em Mirobriga (Santiago do Cacém): contributo a partir de um estudo de caso Filipe Sousa / Catarina Felício

${ }_{1385}$ O fim do ciclo. Saneamento e gestão de resíduos nos edifícios termais de Mirobriga (Santiago do Cacém)

Catarina Felício / Filipe Sousa

1399 Balsa, Topografia e Urbanismo de uma Cidade Portuária Vítor Silva Dias / João Pedro Bernardes / Celso Candeias / Cristina Tété Garcia

1413 No Largo das Mouras Velhas em Faro (2017): novas evidências da necrópole norte de Ossonoba e da sua ocupação medieval Ricardo Costeira da Silva / Paulo Botelho / Fernando Santos / Liliana Nunes

1429 Instrumentos de pesca recuperados numa fábrica de salga em Ossonoba (Faro) Inês Rasteiro / Ricardo Costeira da Silva / Paulo Botelho

1439 A Necrópole Romana do Eirô, Duas Igrejas (Penafiel): intervenção arqueológica de 2016 Laura Sousa / Teresa Soeiro

1457 Ritual, descarte ou afetividade? A presença de Canis lupus familiaris na Necrópole Noroeste de Olisipo (Lisboa)

Beatriz Calapez Santos / Sofia Simões Pereira / Rodrigo Banha da Silva / Sílvia Casimiro / Cleia Detry / Francisca Alves Cardoso

1467 Dinâmicas económicas em Bracara na Antiguidade Tardia Diego Machado / Manuela Martins / Fernanda Magalhães / Natália Botica

1479 Cerâmicas e Vidros da Antiguidade Tardia do Edifício sob a Igreja do Bom Jesus (Vila Nova de Gaia) Joaquim Filipe Ramos

1493 Novos contributos para a topografia histórica de Mértola no período romano e na Antiguidade Tardia Virgílio Lopes

\section{8. Época Medieval}

1511 Cerâmicas islâmicas no Garb setentrional "português": algumas evidências e incógnitas Constança dos Santos / Helena Catarino / Susana Gómez / Maria José Gonçalves / Isabel Inácio / Gonçalo Lopes / Jacinta Bugalhão / Sandra Cavaco / Jaquelina Covaneiro / Isabel Cristina Fernandes / Ana Sofia Gomes 
1525 Contributo para o conhecimento da cosmética islâmica, em Silves, durante a Idade Média Rosa Varela Gomes

1537 Yábura e o seu território - uma análise histórico-arqueológica de Évora entre os séculos VIII-XII José Rui Santos

1547 A encosta sul do Castelo de Palmela - resultados preliminares da escavação arqueológica Luís Filipe Pereira / Michelle Teixeira Santos

1559 A igreja de São Lourenço (Mouraria, Lisboa): um conjunto de silos e de cerâmica medieval islâmica

Andreia Filipa Moreira Rodrigues

1571 O registo material de movimentações populacionais no Médio Tejo, durante os séculos XII-XIII. Dois casos de "sunken featured buildings", nos concelhos de Cartaxo e Torres Novas Marco Liberato / Helena Santos / Nuno Santos

1585 O nordeste transmontano nos alvores da Idade média. Notas para reflexão Ana Maria da Costa Oliveira

1601 Sepulturas escavadas na rocha do Norte de Portugal e do Vale do Douro: primeiros resultados do Projecto SER-NPVD

Mário Jorge Barroca / César Guedes / Andreia Arezes / Ana Maria Oliveira

1619 "Portucalem Castrum Novum" entre o Mediterrâneo e o Atlântico: o estudo dos materiais cerâmicos alto-medievais do arqueossítio da rua de D. Hugo, nํ. 5 (Porto) João Luís Veloso

1627 A Alta Idade Média na fronteira de Lafões: notas preliminares sobre a Arqueologia no Concelho de Vouzela

Manuel Luís Real / Catarina Tente

1641 Um conjunto cerâmico medieval fora de portas: um breve testemunho aveirense Susana Temudo

${ }_{1651}$ Os Lóios do Porto: uma perspetiva integrada no panorama funerário da Baixa Idade Média à Época Moderna em meios urbanos em Portugal

Ana Lema Seabra

1659 O Caminho Português Interior de Santiago como eixo viário na Idade Média Pedro Azevedo

1665 Morfologia Urbana: Um exercício em torno do Castelo de Ourém André Donas-Botto / Jaqueline Pereira

1677 Intervenção arqueológica na Rua Marquês de Pombal/Largo do Espírito Santo (Bucelas, Loures)

Florbela Estêvão / Nathalie Antunes-Ferreira / Dário Ramos Neves / Inês Lisboa

1691 O Cemitério Medieval do Poço do Borratém e a espacialidade funerária na cidade de Lisboa Inês Belém / Vanessa Filipe / Vasco Noronha Vieira / Sónia Ferro / Rodrigo Banha da Silva

1705 Um Espaço Funerário Conventual do séc. XV em Lisboa: o caso do Convento de São Domingos da Cidade Sérgio Pedroso / Sílvia Casimiro / Rodrigo Banha da Silva / Francisca Alves Cardoso

\section{9. Época Moderna e Contemporânea}

1721 Arqueologia Moderna em Portugal: algumas reflexões críticas em torno da quantificação de conjuntos cerâmicos e suas inferências históricas e antropológicas Rodrigo Banha da Silva / André Bargão / Sara da Cruz Ferreira

1733 Faianças de dois contextos entre os finais do século XVI e XVIII do Palácio dos Condes de Penafiel, Lisboa

Martim Lopes / Tomás Mesquita 
1747 Um perfil de consumo do século XVIII na foz do Tejo: O caso do Mercado da Ribeira, Lisboa Sara da Cruz Ferreira / Rodrigo Banha da Silva / André Bargão

1761 Os Cachimbos dos Séculos XVII e XVIII do Palácio Mesquitela e Convento dos Inglesinhos (Lisboa)

Inês Simão / Marina Pinto / João Pimenta / Sara da Cruz Ferreira / André Bargão / Rodrigo Banha da Silva

1775 "Tomar os fumos da erua que chamão em Portugal erua sancta». Estudo de Cachimbos provenientes da Rua do Terreiro do Trigo, Lisboa

Miguel Martins de Sousa / José Pedro Henriques / Vanessa Galiza Filipe

1787 Cachimbos de Barro Caulínitico da Sé da Cidade Velha (República de Cabo Verde)

Rodrigo Banha da Silva / João Pimenta / Clementino Amaro

1801 Algumas considerações sobre espólio não cerâmico recuperado no Largo de Jesus (Lisboa) Carlos Boavida

1815 Adereços de vidro, dos séculos XVI-XVIII, procedentes do antigo Convento de Santana de Lisboa (anéis, braceletes e contas)

Joana Gonçalves / Rosa Varela Gomes / Mário Varela Gomes

1837 Da ostentação, luxo e poder à simplicidade do uso quotidiano: arqueologia e simbologia de joias e adornos da Idade Moderna Portuguesa Jéssica Iglésias

1849 Os amuletos em Portugal - dos objetos às superstições: o coral vermelho Alexandra Vieira

1865 Cerâmicas de Vila Franca de Xira nos séculos XV e XVI Eva Pires

1879 «Não passa por teu o que me pertence». Marcas de individualização associadas a faianças do Convento de Nossa Senhora de Aracoeli, Alcácer do Sal Catarina Parreira / Íris Fragoso / Miguel Martins de Sousa

1891 Cerâmica de Leiria: alguns focos de produção

Jaqueline Pereira / André Donas-Botto

1901 Os Fornos na Rua da Biquinha, em Óbidos Hugo Silva / Filipe Oliveira

1909 A casa de Pêro Fernandes, contador dos contos de D. Manuel I: o sítio arqueológico da Silha do Alferes, Seixal (século XVI) Mariana Nunes Ferreira

1921 O Alto da Vigia (Sintra) e a vigilância e defesa da costa Alexandre Gonçalves / Sandra Santos

1937 O contexto da torre sineira da Igreja de Santa Maria de Loures Paulo Calaveira / Martim Lopes

1949 A Necrópole do Hospital Militar do Castelo de São Jorge e as práticas funerárias na Lisboa de Época Moderna Susana Henriques / Liliana Matias de Carvalho / Ana Amarante / Sofia N. Wasterlain

1963 SAND - Sarilhos Grandes Entre dois Mundos: o adro da Igreja e a Paleobiologia dos ossos humanos recuperados

Paula Alves Pereira / Roger Lee Jesus / Bruno M. Magalhães

1975 Expansão urbana da vila de Cascais no século XVII e XVIII: a intervenção arqueológica na Rua da Vitória no 15 a 17

Tiago Pereira / Vanessa Filipe

1987 Novos dados para o conhecimento do Urbanismo de Faro em época Moderna Ana Rosa 
1995 Um exemplo de Arqueologia Urbana em Alcoutim: o Antigo Edifício dos CTT Marco Fernandes / Marta Dias / Alexandra Gradim / Virgílio Lopes / Susana Gómez Martínez

2007 Palácio dos Ferrazes (Rua das Flores/Rua da Vitória, Porto): a cocheira de Domingos Oliveira Maia

Francisco Raimundo

2021 As muitas vidas de um edifício urbano: História, Arqueologia e Antropologia no antigo Recreatório Paroquial de Penafiel Helena Bernardo / Jorge Sampaio / Marta Borges

2035 O convento de Nossa Senhora da Esperança de Ponta Delgada: o contributo da arqueologia para o conhecimento de um monumento identitário João Gonçalves Araújo / N’Zinga Oliveira

2047 Arqueologia na ilha do Corvo... em busca da capela de Nossa Senhora do Rosário Tânia Manuel Casimiro / José Luís Neto / Luís Borges / Pedro Parreira

2059 Perdidos à vista da Costa. Trabalhos arqueológicos subaquáticos na Barra do Tejo Jorge Freire / José Bettencourt / Augusto Salgado

2071 Arqueologia marítima em Cabo Verde: enquadramento e primeiros resultados do projecto CONCHA

José Bettencourt / Adilson Dias / Carlos Lima / Christelle Chouzenoux / Cristóvão Fonseca / Dúnia Pereira / Gonçalo Lopes / Inês Coelho / Jaylson Monteiro / José Lima / Maria Eugénia Alves / Patrícia Carvalho / Tiago Silva

2085 Trabalhos arqueológicos na Cidade Velha (Ribeira Grande de Santiago, Cabo Verde): reflexões sobre um projecto de investigação e divulgação patrimonial André Teixeira / Jaylson Monteiro / Mariana Mateus / Nireide Tavares / Cristovão Fonseca / Gonçalo C. Lopes / Joana Bento Torres / Dúnia Pereira / André Bargão / Aurélie Mayer / Bruno Zélie / Carlos Lima / Christelle Chouzenoux / Inês Henriques / Inês Pinto Coelho / José Lima / Patrícia Carvalho / Tiago Silva

2103 A antiga fortificação de Quelba / Khor Kalba (E.A.U.). Resultados de quatro campanhas de escavações, problemáticas e perspectivas futuras Rui Carita / Rosa Varela Gomes / Mário Varela Gomes / Kamyar Kamyad

2123 Colónias para homens novos: arqueologia da colonização agrária fascista no noroeste ibérico Xurxo Ayán Vila / José Mạ . Señorán Martín 


\title{
RETRACTOS DA ARQUEOLOGIA PORTUGUESA NA IMPRENSA: (IN)VISIBILIDADES NO FEMININO
}

\author{
Catarina Costeira ${ }^{1}$, Elsa Luís ${ }^{2}$
}

\begin{abstract}
RESUMO
Partindo da presença da arqueologia portuguesa nos meios de comunicação social, com especial destaque para a imprensa escrita digital dos últimos dez anos, discute-se a visibilidade feminina dentro da profissão e como esta é transmitida para a sociedade.

Considerando as fontes citadas nas notícias de arqueologia como representativas da distribuição de mulheres em diferentes sectores da actividade arqueológica e os respectivos cargos que ocupam, é surpreendente a disparidade encontrada entre fontes masculinas e femininas, especialmente numa altura em que teremos atingido a paridade de género nos profissionais de arqueologia no activo. Esta maior invisibilidade feminina contribui para a manutenção de preconceitos de género e limita os exemplos que passamos para as novas gerações.

Palavras-chave: Arqueologia de género, Arqueologia no feminino, Meios de Comunicação, Estratégias de Comunicação.
\end{abstract}

\begin{abstract}
In this paper, we address the visibility of women in Portuguese archaeology and how that image is perceived by the society, through the lens of the digital written press of the last ten years.

Considering sources found in archeology news as a representation of the distribution of women in different areas of archaeological activity, and their respective positions, we've noticed a surprising disparity found in male and female sources, especially at a time when we have reached gender parity in active archeology professionals. This female invisibility contributes to the maintenance of gender prejudices and limits the examples that we pass on to the new generations.
\end{abstract}

Keywords: Gender Archaeology, Women in Archaeology, Media, Communication Strategies.

\begin{abstract}
"A diferença de critério com que se encara, no nosso país, o trabalho profissional feminino, em relação ao lar, conforme as diversas classes, marca um aspecto muito importante da vida da mulher, da sua própria mentalidade e também da mentalidade do homem, assim como das normas que predominam na sociedade"
\end{abstract}

Maria Lamas, Mulheres do meu País, 1948

\section{INTRODUÇÃO}

A consolidação da arqueologia enquanto disciplina científica autónoma em Portugal remonta à segunda metade do século XIX, acompanhando, ainda que com um ritmo próprio, as principais tendências da arqueologia europeia e mundial (Diniz e Gonçalves, 1993-1994; Fabião, 1999). Apesar desta longevidade e de um evidente crescimento e dinamismo nas últimas décadas, a história da arqueologia portuguesa é um tema pouco abordado, centrando-se sobretudo nos alvores da disciplina e nos arqueólogos

\footnotetext{
1. Centro de Arqueologia da Universidade de Lisboa Uniarq / Núcleo de Arqueologia da Câmara Municipal de Sintra; catarinacosteira@gmail.com
}

2. Centro de Arqueologia da Universidade de Lisboa Uniarq / NewsMuseum; elsavluis@gmail.com 
pioneiros, muitas vezes apresentados como figuras tutelares. Esta falta de reflexão sobre as condições e circunstâncias da produção de conhecimento arqueológico e dos seus autores ao longo do tempo torna mais difícil a construção da memória e consciência profissional e científica por parte dos arqueólogos portugueses.

Apesar de alguns trabalhos mais recentes terem como intento a caracterização e quantificação dos arqueólogos e trabalhos de arqueologia em Portugal (Costa et al., 2014; Bugalhão, 2011; 2013; 2017; Simões, et al., 2018), os dados disponíveis necessitam de um maior aprofundamento. É igualmente essencial estudar a imagem dos arqueólogos na comunidade, como forma de alterar muitos dos estereótipos relacionados com esta atividade e os seus profissionais, sobretudo os que são veiculados pelos meios de comunicação.

$\mathrm{Na}$ atualidade, os meios de comunicação, pelo seu universalismo, rapidez e versatilidade, têm um papel fundamental no acesso de todos os cidadãos à informação, independentemente da sua localização geográfica, dos seus graus académicos, do seu enquadramento social ou económico. O poder e credibilidade dos meios de comunicação tornam-nos agentes essenciais na definição de identidades e na percepção da realidade (Souza, 2014; Savietto; 2015, Martins, 2015). Consideramos que conhecer e refletir sobre a forma como os media abordam a arqueologia portuguesa e os seus profissionais é importante para potenciar o retorno social desta atividade, contribuindo para a sua aproximação à comunidade. Começámos por estudar a presença da arqueologia portuguesa nos meios de comunicação social através da análise da imprensa escrita digital. No decorrer desta investigação deparamo-nos com uma grande diversidade de problemáticas, selecionando para o presente trabalho a diferença na representatividade entre arqueólogos e arqueólogas nos meios de comunicação.

Tal como muitos estudos têm vindo a demonstrar (Cerqueira, 2008; Mota-Ribeiro e Pinto-Coelho, 2005; Magalhães e Alvarez, 2014, Souza, 2014; Martins, 2013; Martins, 2015; Savietto, 2015; Sabbati et al., 2018), a representação do género feminino nos meios de comunicação portugueses é ainda muito desigual e estereotipada, apesar do longo caminho de emancipação feminina que tem sido desbravado desde o início do século XX, acentuado a partir da Revolução de 1974. Com efeito, a imagem da mulher veiculada pela comunicação social não reflete na plenitude o seu papel cada vez mais presente e interventivo a nível profissional, científico, político e social. No caso concreto da arqueologia portuguesa, em que se atingiu a paridade de género em termos profissionais (Bugalhão, 2017 b), é surpreendente o silêncio dos meios de comunicação em torno de arqueólogas com percursos cientificamente relevantes e a desproporção entre fontes masculinas identificadas e fontes femininas anónimas ou ausentes. De facto, o crescimento de arqueólogas em Portugal, a partir sobretudo da década de 1970, não foi acompanhado de uma mudança de paradigma nos modos de fazer e pensar a arqueologia, mantendo-se uma disciplina dominada por temas e comportamentos androcêntricos. As abordagens integradas na designada Arqueologia de Género, tal como muitas outras correntes pós-processualistas, têm-se desenvolvido de forma tímida em Portugal (Diniz, 2006), situação que, apesar de tudo, parece estar a mudar nas primeiras décadas do século XXI, com o aumento de iniciativas (colóquios, seminários, artigos e inquéritos) que promovem a reflexão sobre a presença e o papel da mulher na prática arqueológica e a crítica a um Passado demasiado masculino, em que as mulheres ou não têm lugar ou desempenham sempre o papel secundário (Boaventura, 2011; Bugalhão, 2013; Gomes, 2011 e 2015; Vale, 2015 e Martins, 2016).

Com este trabalho esperamos contribuir para a reflexão sobre a sub-representação das arqueólogas nos meios de comunicação portugueses na atualidade e para a necessidade de consolidar o conhecimento sobre o papel destas profissionais ao longo da história da disciplina e desta forma aproximar a imagem que a comunidade constrói da arqueologia e dos seus profissionais da atualidade.

\section{A ARQUEOLOGIA PORTUGUESA NA IMPRENSA ESCRITA DIGITAL, CONTEXTO E METODOLOGIA}

Recentemente realizámos um estudo preliminar sobre a presença da arqueologia portuguesa nos meios de comunicação social, tomando como caso de estudo a imprensa escrita digital (Luís e Costeira, no prelo).

O objectivo geral desse trabalho foi o de avaliar a quantidade e qualidade de notícias sobre arqueologia portuguesa tendo como base a imprensa escrita digital ao longo de dez anos de publicações, entre 
2009-2019. Foram, neste contexto, consultados jornais nacionais generalistas de grande divulgação, como o Expresso, Público, Observador, Correio da Manhã, Sol, Jornal I, Jornal de Notícias e Diário de Notícias, recorrendo aos motores de busca online de cada jornale/ou utilizando filtros com palavras-chave relacionadas com a actividade arqueológica nas suas variadas valências, como escavações arqueológicas, projectos de investigação, sítios e materiais arqueológicos, museus de arqueologia, e também condições laborais e legislação sobre arqueologia. Nesta análise, não foram considerados artigos de opinião. As notícias recuperadas deverão constituir uma parte da totalidade de notícias produzidas no período enunciado, na medida em que não existe uma obrigatoriedade em manter um arquivo online, nem único nem de cada jornal, em canal aberto para o público geral, nem se verifica uma uniformização das notícias que ainda se mantêm online; deparámo-nos, por exemplo, com casos em que apenas se conserva o título e a data da notícia. Os próprios sites dos jornais portugueses não dispõem de um sistema de pesquisa avançada e limitam o número de resultados por cada pesquisa e/ou por cada palavra-chave, sendo necessário realizar várias pesquisas, com diferentes palavras-chave, para se obter a maior quantidade possível de resultados. Um outro constrangimento prende-se com o acesso restrito em vários destes jornais online, que, procurando maximizar a sua receita, limitam a quantidade de notícias de acesso livre, estando apenas disponível o título e o lead. Estas notícias de acesso reservado foram consideradas, ficando, no entanto, condicionado o total preenchimento dos campos de análise. Ainda equacionámos adquirir o acesso a um ou mais jornais online, porém, para percebermos qual é, realmente, a informação que pode chegar a todos os cidadãos, de forma mais universal e sem restrições financeiras, optámos por utilizar os recursos que estão disponíveis online de forma gratuita. Acreditamos que a contratualização de um serviço de clipping poderia colmatar estas lacunas, mas, atendendo à natureza preliminar destes estudos e aos elevados custos que estes serviços acarretam, optámos por realizar a pesquisa manualmente.

Apesar de todos estes constrangimentos metodológicos, consideramos que o conjunto de notícias recuperado deverá constitui uma eficaz amostragem e que nos permite extrair considerações importantes sobre a imagem da disciplina e dos seus agentes.
Entre as várias observações e conclusões a que esse estudo inicial nos permitiu chegar, destacamos as mais relevantes para um melhor enquadramento do papel da mulher na arqueologia portuguesa, visto através dos meios de comunicação social. Assim, verificámos que os jornais que mais publicam notícias de arqueologia são o Público e o Diário de Notícias e, tendencialmente, apresentam notícias mais completas e desenvolvidas (Gráfico 1). Ao longo do período analisado verificou-se uma tendência crescente de publicação de notícias com temáticas arqueológicas, com pico centrado nos anos de 2017 e 2018, o que coincide com um crescimento generalizado de trabalhos arqueológicos e do número de arqueólogos em actividade (Bugalhão, 2017b). Neste particular, é notório também o crescimento da arqueologia empresarial preventiva, que trouxe novas fontes de financiamento privadas à actividade arqueológica, permitindo a entrada e manutenção de novos profissionais. Por outro lado, este aumento de notícias traduz também a existência de transformações dentro da própria comunidade arqueológica, especialmente nas universidades, centros de investigação e empresas de arqueologia, que vão aumentando a sua preocupação com a comunicação da sua actividade ao grande público e criando rúbricas de comunicação e divulgação dentro dos seus próprios projectos, até para tentar garantir os mesmos níveis de financiamento após a crise financeira de 20082011 (a título de exemplo vide Pereira, 2020).

Os temas mais procurados (Gráficos 2 e 3), ou seja, com maior quantidade de notícias, são os das Descobertas Arqueológicas, Museus de Arqueologia e Projectos de Investigação, alimentando a curiosidade natural do público por estes temas, incluindo o fascínio e deslumbramento pela descoberta, pela novidade, pelo "tesouro enterrado", bem como a divulgação de resultados da investigação e novidades relacionadas com exposições em museus de arqueologia. No caso concreto dos museus de arqueologia, regista-se uma quantidade significativa de notícias relacionadas com questões de gestão e administração que denotam uma preferência pelo enquadramento político deste assunto. Evidenciam-se os casos do Museu Nacional de Arqueologia, com 64 notícias, nas quais se destaca o debate sobre a sua possível transferência para outro edifício em Lisboa e as notícias relacionadas com a nomeação do director; e o do Museu e Parque do Côa, com 122 notícias, sobressaindo os temas da direcção e gestão da fundação e do museu. 
Os temas relacionados com questões sociais e laborais da profissão, como as condições de trabalho, as instituições da tutela e algumas notícias sobre arqueólogos, surgem em menor quantidade, podendo a sua maior visibilidade estar associada à criação do sindicato de arqueologia, STARQ, que ocorreu dentro do período considerado (Mesquita e Simões, 2014).

É frequente o recurso a declarações de diversificadas fontes nas notícias de arqueologia, nomeadamente pedidas a representantes de instituições públicas como a Direção Geral do Património Cultural (DGPC), as Direções Regionais de Cultura (DRC), o Ministério da Cultura e as Câmaras Municipais; das Universidades e Centros de Investigação; dos Museus de Arqueologia, com especial destaque para o Museu Nacional de Arqueologia; e também de profissionais em nome individual, empresas de arqueologia, profissionais das arqueociências, e ainda de instituições profissionais como o Sindicato de Arqueologia ou a Associação de Arqueólogos Portugueses. Neste tema concreto, chamou-nos a atenção o facto de termos registado uma diferença muito significativa entre fontes masculinas e fontes femininas, sobretudo numa altura em que já teremos atingido a igualdade de género na profissão (Bugalhão, 2017 a; Simões et al., 2018), surgindo a necessidade de compreendermos as razões subjacentes. É neste encadeamento que surgiu a motivação para este trabalho, sobretudo no contexto actual, ainda inspirado pelo movimento internacional $\mathrm{Me}$ Too, em que se debatem muitas questões relacionadas com o género, como a igualdade no trabalho, no vencimento, no acesso aos cargos de decisão e de direcção, nas questões de família e parentalidade, entre outras. Procuramos, neste pequeno ensaio, analisar de que forma é que a arqueóloga (ou outra profissional relacionada com a arqueologia) se encontra representada nos meios de comunicação social, qual é a imagem que é transmitida, e que exemplos estamos a construir para as gerações futuras. Não se trata apenas de analisar os números da representatividade, ainda que, por si, revelem muito, mas também de questionar qual a imagem do arqueólogo da actualidade e como a mulher se enquadra nessa imagem.

Para este fim, partimos da base de dados de notícias que recolhemos anteriormente, com o mesmo intervalo de tempo, 2009-2019, e concentrámo-nos nos descritores que melhor nos poderiam ajudar a reflectir sobre estas temáticas, como a quantidade de notícias e sua evolução no tempo, os temas mais representados, e, sobretudo, as fontes utilizadas nas notícias, o relevo que é dado aos profissionais da área e qual o seu género. Destacámos as notícias que atribuíam relevância ao arqueólogo/a, quer de forma biográfica, quer pela sua actividade laboral e/ou científica, e ainda as que nos revelam em que contextos encontramos mulheres referidas nas notícias, qual o seu cargo e qual o destaque que lhes é atribuído, sempre em comparação com o que é dado aos elementos do sexo masculino.

\section{MULHERES COMO FONTES NAS NOTÍCIAS DE ARQUEOLOGIA}

Partindo de uma amostra de 1279 notícias, a sua grande maioria refere ou cita uma ou mais fontes que complementam a informação disponibilizada e conferem maior credibilidade à própria notícia, sendo relevante referir que apenas 128 entradas não mencionam fontes.

Dentro das fontes mencionadas, e retiradas as que apenas indicam a instituição consultada, destacamos as que nos permitem aferir qual o género, quer pelo nome, quer pelo pronome utilizado: 528 homens e 221 mulheres, perfazendo, como o gráfico abaixo indica, $70 \%$ e 30\%, respectivamente (Gráfico 4).

Em várias notícias são referidos arqueólogos e arqueólogas como parte de projectos de investigação ou outro tipo de trabalhos arqueológicos, aos quais não são pedidas declarações, pelo que não foram considerados para esta estatística de fontes.

Se olharmos para a presença de fontes femininas em comparação com a evolução do volume de notícias nos dez anos considerados (Gráfico 5), verificamos que não parece haver um acompanhamento das fontes femininas ao aumento de notícias. Esta situação poderá ser justificada pela forte presença de profissionais masculinos ligados à arqueologia em cargos de responsabilidade/decisão, aliada ao mais recente crescimento de mulheres no sector. Contudo, também pode refletir a secundarização das vozes femininas nos meios de comunicação, mantendo a esfera pública no domínio masculino. Com efeito, os meios de comunicação portugueses continuam a privilegiar o especialista/cientista homem como fonte de informação segura, mantendo as figuras femininas num plano secundário, o que obviamente vai contribuir para manter a desigualdade de representa- 
ções de género na sociedade. Estas representações são tão enraizadas que as mulheres não têm consciência desta desigualdade, considerando que têm a mesma oportunidade de se expressar nos meios de comunicação, o que não é acompanhado pelos dados quantitativos (Lobo e Cabecinhas, 2013; Martins, 2013; Savietto, 2015; Sabbati et al., 2018). Esta sub-representação feminina nos meios de comunicação está associada às lógicas de mediação, à permanência de perspetivas masculinas apresentadas como neutras (Martins, 2013) e à falta de consciência feminina desta barreira invisível de falta de expressão, devido à interiorização, desde a infância, "(...) de um conjunto de atitudes que tende (...) a manter uma postura submissa por parte das mulheres nas diversas esferas sociais" (Viegas e Faria, 2001).

Este silêncio das vozes femininas nos meios de comunicação é acompanhado pelo silêncio na própria academia, com a manutenção de discursos explicitamente androcêntricos sobre o Passado e a falta de uma reflexão escrita sobre estas temáticas (Vale, 2015).

Estes exemplos, a que se podiam associar muitos outros, evidenciam a insuficiente democratização da esfera privada e quotidiana em Portugal (Gomes, 2011; Martins, 2013), com a consequente manutenção de muitos dos valores patriarcais e masculinos, perpetuando-se a figura cimeira e, por vezes, exclusiva do pai - "chefe de família", em muita da documentação oficial basilar dos indivíduos e nas cerimónias e tomadas de decisão das mais diversas instituições do país. Os cenários de poder e a História, mesmo da Revolução e da Democracia, são palcos maioritariamente masculinos, em que faltam e se esquecem as personagens femininas.

\section{O ARQUEÓlOGO E A ARQUEÓlOGA COMO TEMA DE NOTÍCIA}

Os meios de comunicação social são, indiscutivelmente, guardadores de memórias, uma parte do nosso arquivo social, cultural, económico, político, entre tantos outros. Não só nos informam da actualidade, como recuperam acontecimentos, reorganizam a informação e têm a capacidade de, como agora muito se fala, contar histórias e estórias. Esta capacidade de trazer para a visibilidade e discussão públicas uma enorme diversidade de assuntos e temas é fundamental para a construção da nossa percepção do real e da forma como nos relacionamos
(Gonçalves, 2004/05; Martins, 2013). Estes meios de comunicação têm ainda o poder de construir (e destruir) a imagem que cada um de nós tem sobre um indivíduo ou uma classe profissional, e destacar e homenagear percursos profissionais ou contributos para determinadas áreas da sociedade. Neste sentido, a periodicidade com que temas de arqueologia são abordados e a forma como os arqueólogos são retratados nos meios de comunicação serão fundamentais para a construção da imagem pública da disciplina e da classe profissional e para o seu reconhecimento social.

Contabilizamos o número de notícias que se centram na figura do arqueólogo, que destacam a pessoa pelo seu percurso profissional e por ter ganhado visibilidade nacional e/ou internacional. Das 27 notícias que têm como tema principal o arqueólogo, apenas três se referem a mulheres, números que demonstram bem a diferença mediática entre os géneros: “Arqueóloga Maria Antónia Amaral é a nova directora do castelo de São Jorge" (Expresso, 19 Junho 2019); "Uma egiptóloga portuguesa a ensinar em Harvard? Sim, éa Inês" (Público, 27 de Maio de 2018); "Nas antas do Alentejo já se falou alemão" (Público, 20 de Agosto de 2015). De destacar que temos uma notícia de 2015 que refere um casal de arqueólogos, Georg e Vera Leisner, sublinhando como era uma mulher excepcional, por estar em pé de igualdade com o marido; e duas notícias já bem recentes, 2018 e 2019, uma que destaca um cargo político e outra uma investigadora com sucesso internacional.

As notícias de cariz biográfico, que incluem arqueólogos de diferentes gerações, e os obituários que analisamos referem-se exclusivamente a homens. O mérito profissional e pessoal dos arqueólogos referidos nestas notícias, como por exemplo Cláudio Torres, João Zilhão, António Martinho Baptista, ou Albano Belino é inegável, contudo, se pensarmos na quantidade e diversidade de arqueólogas, que desde os anos 60 se têm destacado a nível nacional e internacional (vide Bugalhão, 2013, com vários nomes citados), este vazio torna-se mais difícil de explicar, consistindo numa opção dos jornalistas e das redações e não a ausência real de arqueólogas. De facto, a notabilidade profissional e a liderança feminina são ainda vistas pela sociedade como algo estranho, raro e mesmo inapropriado, independentemente da posição política, o que é potenciado por esta invisibilidade nos meios de comunicação.

A ausência de biografias de arqueólogas nos meios 
de comunicação é uma forma subtil de as manter na sombra, tornando mais difícil às profissionais mais novas encontrarem referências no feminino e ampliarem as suas expetativas e ambições. As assimetrias de género no plano da memória histórica consistem num significativo entrave ao empoderamento feminino, porque condicionam as expetativas profissionais e pessoais, perpetuando papéis sociais anacrónicos.

\section{REPRESENTAÇÃO DAS MULHERES EM DIFERENTES CONTEXTOS}

Se observarmos o Gráfico 6, verificamos que o enquadramento profissional mais frequente das arqueólogas citadas como fontes é a categoria designada por "arqueólogas", que inclui profissionais independentes e profissionais em que, estando associadas a instituições, nomeadamente empresas, essa relação não é referida; e a categoria das "universidades”, em que se inclui professoras e investigadoras. Estes dados reflectem o grande crescimento das mulheres no ensino superior e no mercado de trabalho. De facto, a percentagem de mulheres nas licenciaturas, mestrados e doutoramentos em arqueologia, entre 2009 e 2019, situa-se entre os $53 \%$ e os $56 \%$ (Costa et al., 2014; Bugalhão, 2017 a e 2017 b; Diniz, 2019), tendo uma tendência de crescimento, em sintonia com as médias nacionais e europeias (Lazar et al., 2014), o que demonstra a igualdade no acesso aos vários níveis de ensino graduado e pós-graduado. No entanto, se procurarmos a presença feminina em cargos de liderança nas universidades e nos centros de investigação, o seu destaque já não é tão evidente. Não deixa de ser significativa a desproporção entre as fontes masculinas, 149 entradas, e femininas, 57 entradas, nas notícias relacionadas com a investigação científica e universidades. Com efeito, para o número de mulheres nos cursos pós-graduados e como bolseiras de investigação, a representação de arqueólogas - investigadoras parece-nos muito diminuta. O número expressivo de "arqueólogas" como fontes de informação ajusta-se ao crescimento feminino no mercado de trabalho, e é evidente sobretudo no número de direcções científicas (Bugalhão, 2017 a). Consideramos que estes dados devem ser detalhados no futuro, procurando-se determinar não só o número de direcções, mas o de arqueólogas que exercem a profissão mesmo que não dirijam trabalhos e assim aferir qual é o real peso das direcções femininas. Por outro lado, seria igualmente interessante perceber que tipo de trabalhos arqueológicos são normalmente dirigidos por mulheres, qual a sua duração, dimensão das equipas e localização geográfica e assim tentar compreender se as arqueólogas têm mais constrangimentos nas deslocações e / ou nos horários.

Se relacionarmos a percentagem de "arqueólogas" (32\%) com a percentagem de "arqueólogas associadas a empresas" (5\%) a desproporção é muito significativa, o que parece reflectir a grande quantidade de profissionais independentes (precários) e a fraca representação feminina nas lideranças das empresas de arqueologia de média e grande dimensão. Em termos globais, estes dados aproximam-se dos registados para a globalidade do sector empresarial português (Rodrigues, 2017; CCIG, 2017), demonstrando a desigualdade no acesso aos mais altos cargos das hierarquias organizacionais privadas, com consequente desperdício de talento e especialização.

No que se refere à presença de mulheres em instituições públicas da administração local (câmaras municipais) e central (tutela), os dados apresentados são reduzidos em termos gerais. No entanto, a desproporção de género não nos parece tão significativa, pelo menos numa primeira observação, já que encontramos várias mulheres em cargos relacionados com a cultura e o património, como pelouros de vereadores municipais ou o próprio ministério da cultura. Porém, numa análise mais cuidada no que diz respeito às notícias cujo tema são as instituições de tutela, encontramos uma diferença substantiva no recurso a fontes masculinas e femininas, contabilizando estas últimas metade das primeiras ( 27 masculinas e 13 femininas).

Como vários investigadores têm chamado a atenção (Martins, 2013, 2015; Almeida, 2016), a presença de mulheres na política portuguesa é ainda diminuta, situação que tem vindo a mudar lentamente, sobretudo no que se refere aos cargos mais destacados do país. Em termos de pastas ministeriais, a saúde, a educação e a cultura são as que apresentam maior presença feminina, o que pode ajudar a explicar a sensação de menor desigualdade de género nas autarquias e na tutela. Contudo, a total ausência de mulheres em áreas como as obras públicas ou a economia, acabam por manter a invisibilidade em muitos dos cenários e decisões relevantes para a arqueologia. Os cargos de liderança dos museus e associações profissionais são tendencialmente desempenha- 
dos por homens, quer nas instituições centenárias, como o Museu Nacional de Arqueologia ou a Associação dos Arqueólogos Portugueses, quer nas instituições fundadas mais recentemente, como o Campo Arqueológico de Mértola, o Museu e Parque do Côa ou mesmo o Sindicato dos Trabalhadores de Arqueologia. Neste particular, as fontes acabam por corroborar esta situação, com um contraste de 96 fontes masculinas com 30 fontes femininas.

Esta falta de representação feminina nos principais cargos de liderança, mesmo de instituições constituídas em democracia, ajuda a explicar a menor visibilidade mediática das arqueólogas (Martins, 2013) e está sobretudo associada a elementos culturais (preconceitos, atitudes discriminatórias na divisão dos papéis por géneros), muito resistentes à mudança, uma vez que o número e a qualificação das mulheres em arqueologia, tal como em muitas outras áreas científicas e técnicas, são cada vez mais significativas e diferenciadas.

\section{A IMAGEM DO PROFISSIONAL DE ARQUEOLOGIA ATRAVÉS DOS MEDIA}

A imagem que a comunidade portuguesa tem do arqueólogo é muito influenciada pelos meios de comunicação, cinema e literatura. No imaginário português e europeu, o arqueólogo é um homem, branco, europeu, culto, despistado, vestido de forma pouco convencional, solitário e economicamente desafogado, coincidindo ainda com a imagem romântica do explorador/descobridor do final do século XIX, inícios do século XX (Ibáñez Alfonso, 2015). Esta imagem, evidente em muitas das descrições de investigadores - arqueólogos, realizadas pelos meios de comunicação, está associada à valorização da escavação/descoberta enquanto tema principal da actividade arqueológica. Esta situação conduz à invisibilidade e desvalorização de outras actividades e funções do arqueólogo, como o trabalho de laboratório, pesquisa bibliográfica e produção escrita de relatórios, artigos, livros e teses, as etapas de investigação menos financiadas em qualquer contexto laboral português, o que contribui para a falsa ideia de que se o arqueólogo não está no campo não está a fazer nada. Recentemente, com a progressiva visibilidade das descobertas realizadas em contexto urbano, começa a verificar-se, ainda que de forma ténue, alguma mudança na descrição do arqueólogo, evidenciando os diferentes contextos de trabalho e as diferentes tarefas que realiza: "As botas de borracha antes cobertas de lama e os capacetes poeirentos já foram arrumados num canto longe da vista, mas o trabalho dos arqueólogos está longe de chegar ao fim. Agora é em laboratório, entre caixas e tabuleiros repletos de cacos, que se procura escrever mais um capítulo da história da cidade." (Caco a caco, os vestígios romanos da Praça D. Luís I vão ganhando forma, Público, 21 de Abril de 2013).

Outro dos grandes problemas consiste na invisibilidade do trabalho em equipa, herdeira da figura do arqueólogo dos finais do século XIX, quando as relações de trabalho eram muito desiguais e apenas o arqueólogo tinha formação e destaque. Contudo, com a profissionalização da arqueologia e a democratização da sociedade, esta ideia não só é falsa como é arriscada, uma vez que perpetua preconceitos, contribuindo para a precarização e desregulação da actividade. $\mathrm{O}$ arqueólogo deve ser considerado como um elemento de uma equipa, com funções específicas de acordo com a sua formação e contexto laboral; os trabalhos e projectos arqueológicos devem assentar em equipas e não em individualidades.

No imaginário da comunidade, a arqueologia ainda é uma actividade tipicamente masculina, pelas suas características: ao ar livre, em contexto de obra, em territórios distantes, exigindo força, etc. A figura da arqueóloga, em sentido oposto, é vista com algum desconforto, como uma certa transgressão à norma social estabelecida e não como uma actividade profissional, especializada, quotidiana, desenvolvida por uma mãe de família. Veja-se, título de exemplo, como o trabalho da arqueóloga é descrito numa das notícias que consultámos: "Entramos num espaço pequeno onde duas arqueólogas sorridentes andam à volta com esqueletos, montando puzzles complexos e guardando as peças em saquinhos de plástico" ("Cláudio Torres e Mértola", Público, 21 de Abril de 2012). Mas talvez mais significativo seja o próximo exemplo em que, dentro da mesma notícia, se opta por duas descrições bem distintas entre dois arqueólogos, um homem e uma mulher: "Em Reguengos de Monsaraz, António Valera dissolve o calor com a paixão pela arqueologia e à falta de vento responde com o entusiasmo de novas descobertas (...) Se António aparecesse num filme a situação não causava tanta estranheza. Com a barba desalinhada, o pólo e as calças de ganga manchados de terra, exerce a profissão há 27 anos. Ao longo do tempo, muitas descobertas especiais ficaram na sua memória, como a do Verão 
do ano passado (...) Lucy Evangelista, arqueóloga da ERA (...) Sorridente, fala com entusiasmo sobre a povoação. Alta, com sardas e olhos claros, não faz lembrar os arqueólogos dos filmes, habitualmente cobertos de terra." "“Quando 1500 anos de história se contam debaixo dos pés", Público, 9 de Agosto de 2012). O arqueólogo ainda é descrito de forma romantizada, remetendo para uma actividade mais relacionada com as nossas fantasias do que uma ciência e um trabalho técnico especializado.

Esta imagem do trabalho do arqueólogo e do arqueólogo em si, transmitida pela comunicação social, instituições em que a sociedade confia, perpetua muitos dos estereótipos de género e do papel da mulher na sociedade, não esquecendo que "una difusión deficiente (...) puede provocar peores consecuencias que el proprio desconocimiento, ya que el publico pocas veces se cuestiona la veracidad de lo que ve (...), y esas representaciones erróneas, estereotipadas, llegan a influir firmemente en la construcción de la futura percepción popular del ejercicio profesional." (Ibáñez Alfonso, 2015, p. 329).

Existe ainda um longo caminho a percorrer para uma verdadeira igualdade de género no trabalho em arqueologia, e uma parte desse mesmo caminho passa pela divulgação e discussão dos tópicos que aqui apenas aflorámos, e de muitos outros, que contribuam para termos uma mais informada compreensão destes mecanismos, conscientes ou inconscientes, de perpetuação de preconceitos e limitações profissionais impostos às mulheres da profissão, e também para a criação de soluções e alternativas. Uma destas será, assim pensamos, a de divulgar mais o papel das mulheres na arqueologia desde os alvores da disciplina, porque, apesar das dificuldades, sacrifícios e do reduzido número, a sua história merece ser conhecida, potencializando o poder do exemplo. Por outro lado, é necessária uma maior aproximação à comunidade e uma maior clareza na apresentação dos diferentes contextos e ferramentas de trabalho que o arqueólogo utiliza, de maneira a que a profissão se torne mais conhecida e socialmente mais relevante. Uma comunicação da arqueologia que inclua a sua riqueza e diversidade de profissionais, tipos e contextos de trabalho contribuirá, certamente, para a construção de uma imagem mais real e inclusiva desta profissão, mas, simultaneamente, não fará perder o fascínio e a paixão que nos continua sempre a motivar.

\section{BIBLIOGRAFIA}

Recursos digitais, consultados em Janeiro 2020:

www.cmjornal.pt

www.dn.pt

www.expresso.pt

www.ionline.pt

www.jn.pt

www.observador.pt

www.publico.pt

www.sol.sapo.pt

ALMEIDA, M. (2016) - Mulheres na política portuguesa. Em: FERREIRA, E.; VENTURA, I; REGO, L.; TAVARES, M.; ALMEIDA, M.A. (eds). Percursos Feministas: Desafiar os tempos. Universidade Feminista / UMAR., pp. 164-174.

BOAVENTURA, R. (2011) - Bodies in motion. In LILLIOS, K. (ed.) - Comparative archaeologies: The American Southwest $(A D 900-1600)$ and the Iberian Peninsula (30oo 150o BC). Oxford, pp. 209-220.

BUGALHÃO, J. (2011) - Os desafios da Arqueologia portuguesa nas últimas décadas. Arqueologia e História, Lisboa, 6o-61, pp. 19-43.

BUGALHÃO, J. (2013) - As mulheres na arqueologia portuguesa. In ARNAUD, J.; MARTINS, A.; NEVES, C. (coord.) - A arqueologia em Portugal -15o anos. Lisboa, pp. 19-23.

BUGALHÃO, J. (2017a) - O papel da mulher na arqueologia portuguesa. Ophiussa. Lisboa, 1, pp. 123-130.

BUGALHÃO, J. (2017b) - Arqueólogos Portugueses. In ARNAUD, J.; MARTINS, A.; (coord.) - A arqueologia em Portugal-2017 Estado da Questão. Lisboa, pp. 19-32.

CERQUEIRA, C. (2008) - A imprensa e a perspectiva de género. Quando elas são notícia no Dia Internacional da Mulher. Observatorio (OBS) Journal, 5, pp. 139-164.

COMISSÃO PARA A CIDADANIA E IGUALDADE DE GÉNERO (2017) - Poder e tomada de decisão política. Mulheres e homens nos órgãos executivos do poder local.

COMISSÃO PARA A CIDADANIA E IGUALDADE DE GÉNERO (2017) - Poder e tomada de decisão nas empresas: mulheres e homens.

COMISSÃO PARA A CIDADANIA E IGUALDADE DE GÉNERO (2017) - Igualdade de género em Portugal - Boletim estatístico.

COSTA, C., DUARTE, C., TERESO, J., VIEGAS, C., LAGO, M., GRILO, C., RAPOSO, J., DINIZ, M., LIMA, A. (2014) Discovering the Archaeologists of Portugal 2012-14, Associação Profissional de Arqueólogos. Lisboa.

DINIZ, M. (2006) - Para a História das Mulheres na Pré-história: em torno de alguns atributos do discurso. Promontoria, 4, p. 37-51.

DINIZ, M. (2019) - Archaeology PhDs at Portuguese Universities: A Brief Overview of the Last Decade (2010-2018). E-Journal of Portuguese History, 17:2. 
DINIZ, M.; GONÇALVES, V. S. (1993-1994) - Na 2. ํㅡ metade do século XIX: luzes e sombras sobre a institucionalização da arqueologia em Portugal. O Arqueólogo Português, Lisboa, série IV, 11/12, pp. 175-187.

FABIÃO, C. (1999) - Um século de arqueologia em Portugal -I. Al-madan. Almada, série 2, 8, pp. 104-126.

GOMES, F. (2011) - Arqueologia e Género(s): de strange bedfellows a um paradigma de leitura crítica do Passado. Sapiens: História, Património e Arqueologia, 5, pp. 6-30.

GOMES, F. (2015) - Género, identidade e poder: para uma crítica das relações de género em arqueologia. Conímbriga. Coimbra, LIV, pp. 27-44.

GOMES, S. (2011) - O Passado, a identidade e as teias do governo. Estudos sobre os entrelaçamentos das práticas de produção do conhecimento arqueológico e de construção da identidade nacional salazarista. Tese de doutoramento apresentada à Faculdade de Letras da Universidade do Porto.

GONÇALVES, T. (2004/05) - A abordagem do enquadramento nos estudos do jornalismo. Caleidoscópio, 5/6, 157-167.

IBÁÑEZ ALFONSO, M. (2015) - De la realidad al mito. La representación del arqueólogo desde la cultura ilustrada a la cultura de masas. ROMULA. Sevilla, 14, p. 293-331.

LAZAR, I.; KOMPARE, T.; LONDEN, H. (2014) - The Archaeologist of the Future is Likely to be a Woman: Age and Gender Patterns in European Archaeology. Archaeologies: Journal of the World Archaeological Congress, 10, pp. 257-28o.

LOBO, P.; CABECINHAS, R. (2013) - Perspectivas de género no acesso ao espaço público mediatizado: reflectindo sobre os conteúdos noticiosos do telejornal. Estudos em Comunicação, 13, pp. 195236.

LUÍS, E.; COSTEIRA, C. (no prelo) - A arqueologia portuguesa nos meios de comunicação. Comunicação apresentada na sessão 19: No todo es lo que parece: Repensando la educación pública y la divulgación en la Arqueología y en la gestión del Patrimonio de la Península Ibérica. TAG Ibérico, Lisboa, $202 \mathrm{O}$.

MAGALHÃES, S.; ALVAREZ, T. (2014) - Mulheres e Media. Associação Portuguesa de Estudos sobre as Mulheres.

MARTINS, A. (2016) - Pioneiras da arqueologia em Portugal: "Another Brick" against "The Wall" of indifference. María de Lourdes Costa Arthur (1924-2003). Revista Clepsydra, 15, p. 77-100.

MARTINS, C. (2013) - Mulheres, política e visibilidade mediática. As lideranças de Maria de Lourdes Pintasilgo e Manuela Ferreira Leite. Tese de doutoramento apresentada à Faculdade de Ciências Sociais e Humanas da Universidade Nova de Lisboa.

MARTINS, C. (2015) - Mulheres, Liderança Política e Media. Alêtheia Editores
MESQUITA, A.; SIMÕES, S. (2014) - Os trabalhadores de arqueologia portuguesa já têm um sindicato. Al-madan online, Almada, 2ª série, 19, pp. 197-198.

MOTA-RIBEIRO, S.; PINTO-COELHO, Z. (2005) - Imagens de mulheres na imprensa portuguesa. In Actas do IV Congresso da SOPCOM - Repensar os Media: Novos Contextos da Comunicação e da Informação. 20-21 Outubro, Universidade de Aveiro.

PEREIRA, A. (2020) - Análise de Benchmarking e esboço de plano de comunicação estratégico para a Uniarq (Centro de Arqueologia da Universidade de Lisboa). Projecto apresentado na Pós-graduação em gestão e políticas de ciência e tecnologia.

RODRIGUES, M. (2017) - A representatividade das mulheres na liderança de topo. Tese de mestrado apresentada à Faculdade de Economia da Universidade do Porto.

SABBATI, G.; PRPIC, M.; SHREEVES, R. (2018) - Gender equality in the EU's digital and media sectors. European Parliamentary Research Service.

SAVIETTO, D. (2015) - Mulheres e mídia global: uma análise internacional da perspectiva das mulheres sobre suas representações midiáticas. Dissertação de mestrado apresentada à Faculdade de Letras da Universidade de Coimbra.

SIMÕES, S.; BRITO, S.; CARVALHO, L.; BUGALHÃO, J.; MOREIRA, A. (2018) - Questões de género em contexto laboral em arqueologia. Breves notas. Al-madan on-line. Almada, II série (22), tomo 2, pp. 109-111.

SOUZA, J. (2014) - A invisibilidade das mulheres nos media: quando a representação de género define o sexo da notícia. Revista Media e Jornalismo - Da Cidade do México à Aldeia Transnacional. 25, (14-2), pp. 91-103.

VALE, A. (2015) - A mulher e a Pré-história. Alguns apontamentos para questionar a tradição e a tradução da mulher mãe e mulher - deusa na arqueologia pré-histórica. Conímbriga. Coimbra, LIV, pp. 5-25.

VIEGAS, J. M. L.; FARIA, S. (2001) - As Mulheres na Política. Lisboa, Celta. 


\section{Jornais com notícias de Arqueologia}

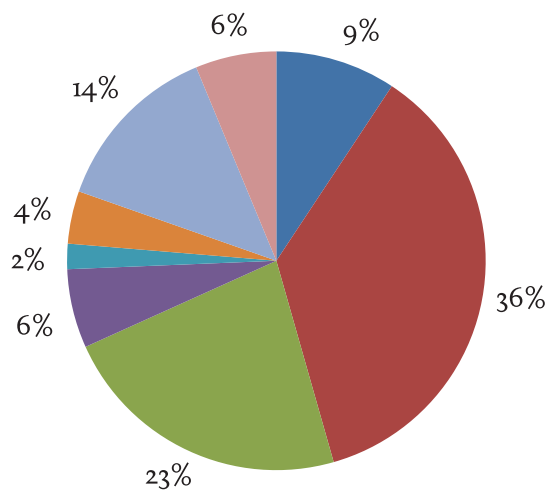
Expresso
- Público
Diário de Notícias
- Jornal de Notícias
- Jornal I
- Sol
- Correio da Manhã
- Observador

Gráfico 1 - Distribuição das notícias de arqueologia pelos jornais generalistas nacionais.

\section{Tema Principal das Notícias}

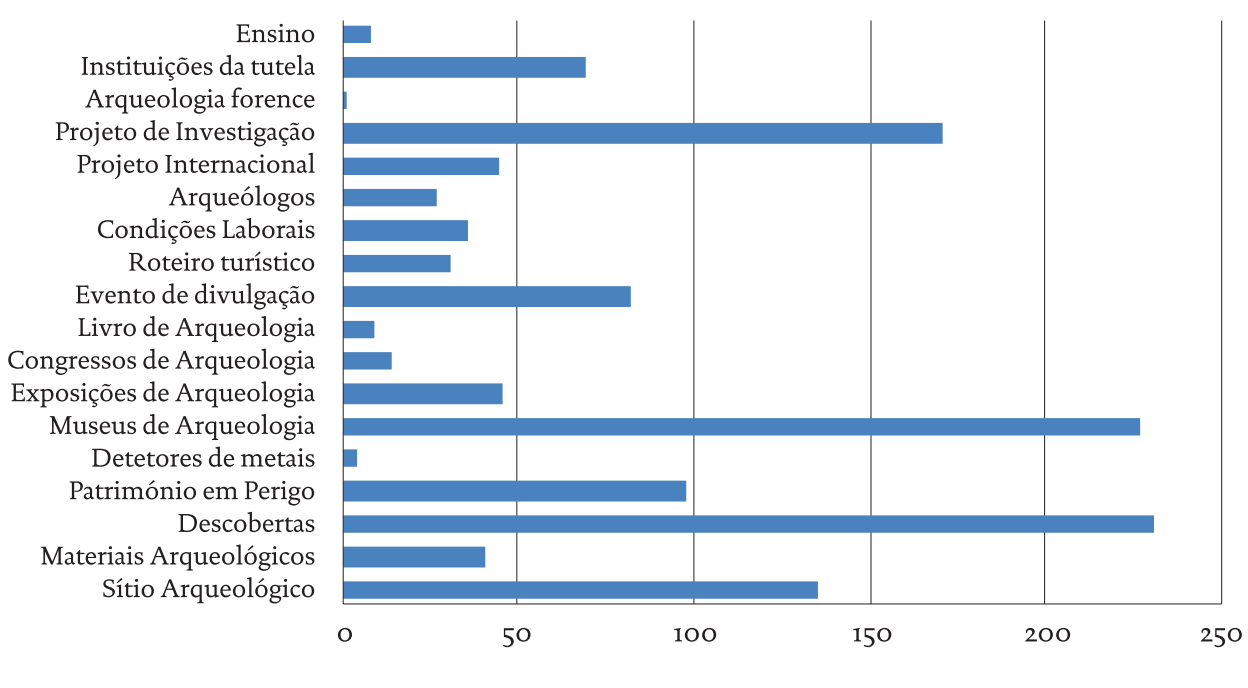

Gráfico 2 - Temas principais das notícias sobre arqueologia.

\section{Dossiers Temáticos}

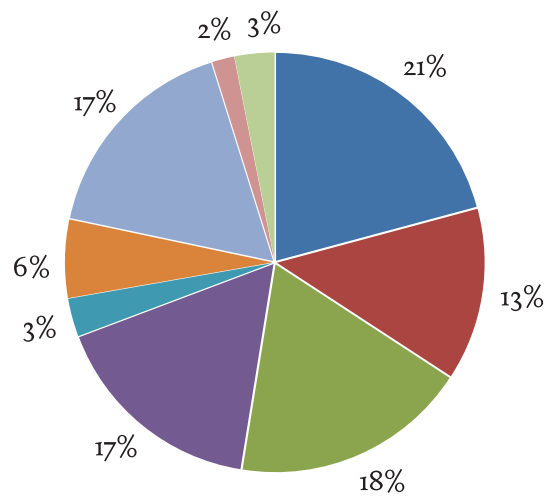
- Arte Rupestre
- Arqueologia Subaquática
- Arqueologia preventiva
- Projecto de Valorização
- Classificação
- Esqueletos
- Escavação
Açores
№ de visitantes

Gráfico 3 - Principais dossiers temáticos das notícias sobre arqueologia. 


\section{Género das Fontes}

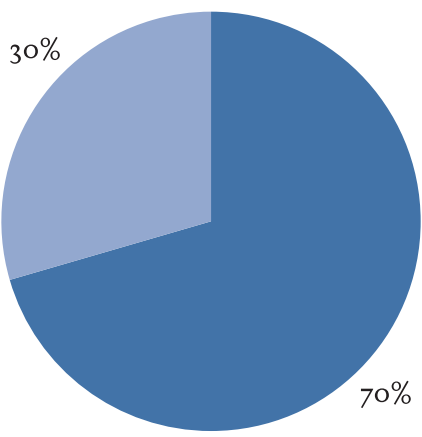

Masculinas

Femininas

Gráfico 4 - Relação entre fontes masculinas e fontes femininas das notícias sobre arqueologia.

\section{Evolução do volume de notícias}

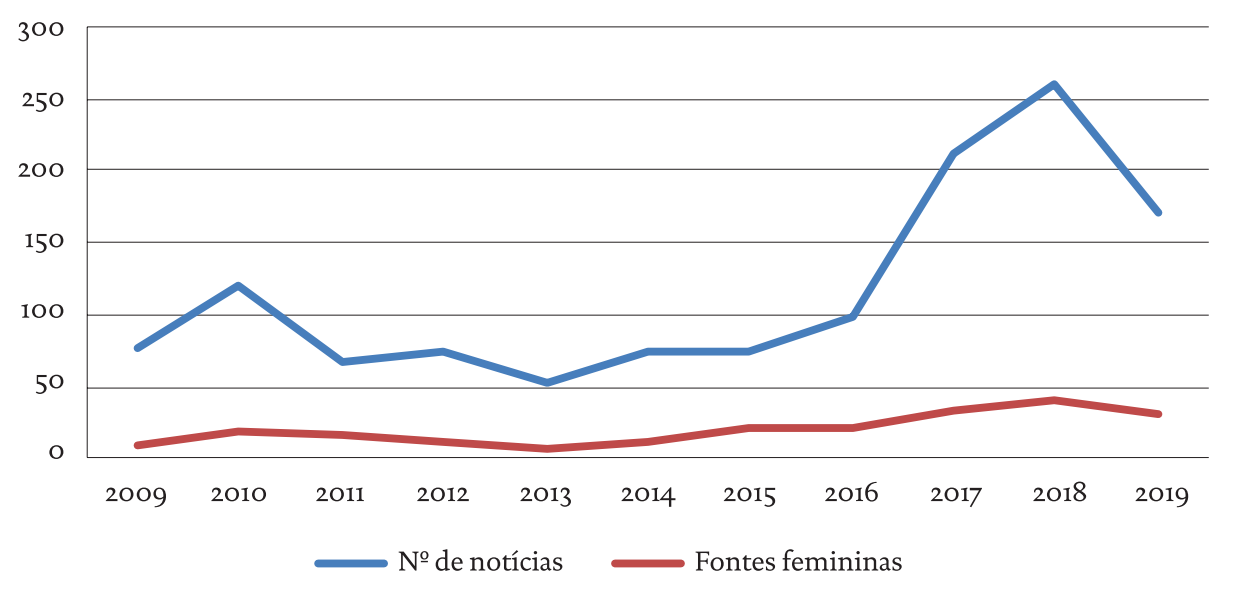

Gráfico 5 - Evolução do número de notícias publicadas sobre arqueologia e do recurso a fontes femininas entre 2009 e 2019 .

\section{Enquadramento profissional das fontes femininas}

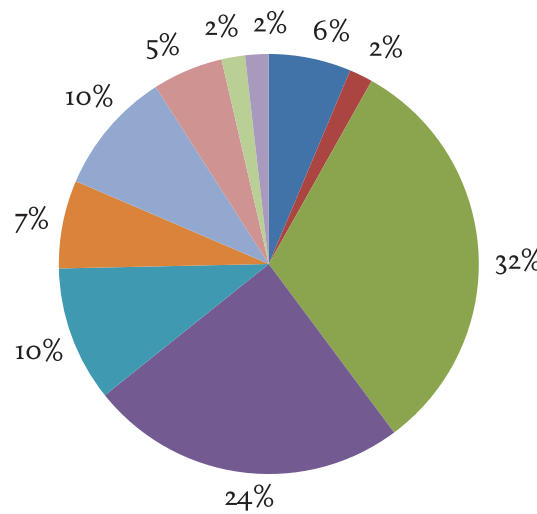

- C.M,

- Instituições

- Arqueólogas

- Universidade

- Tutela

- Antropólogas

- Museus

Empresas

- Sindicato

- Outros

Gráfico 6 - Enquadramento profissional das fontes femininas nas notícias de arqueologia. 


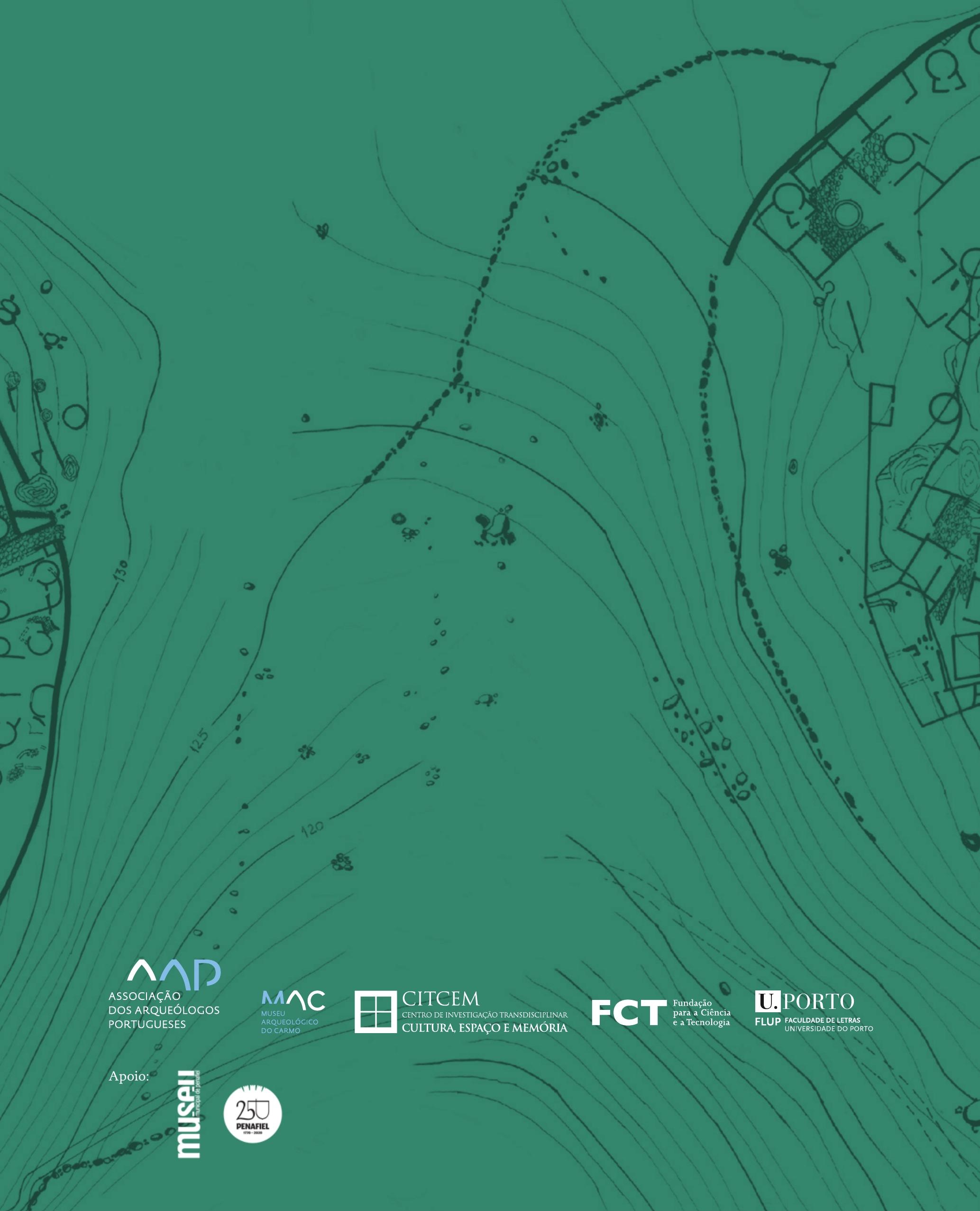

